\title{
Yemeklik Kültür Mantarında (Agaricus bisporus (J. Lge) Imbach) Yaygın Görülen Mikrobiyal Hastalıklar
}

\author{
Nurhan ÖZTÜRK ${ }^{1}$, Esin BASIM ${ }^{2 *}$, Hüseyin BASIM ${ }^{3}$ \\ ${ }^{1}$ Akdeniz Üniversitesi, Korkuteli MYO, Mantarcılık Programı, Antalya \\ ${ }^{2}$ Akdeniz Üniversitesi, Korkuteli MYO, Bahçe Tarımı Programı, Antalya \\ ${ }^{3}$ Akdeniz Üniversitesi, Ziraat Fakültesi, Bitki Koruma Bölümü, Antalya \\ *Sorumlu Yazar: ebasim@yahoo.com; esinbasim@akdeniz.edu.tr
}

\begin{abstract}
Öz
Yenilebilir mantar türleri içinde en yaygın üretime ve tüketimi sahip olan kültür mantarı denilince ilk akla gelen mantar türü Agaricus bisporus'tur. A. bisporus yemeklik tüketilen ve kültüre alınan mantarların başında gelmektir. Kültür mantarının önemi vurgulandığında tüketiminin her geçen gün artması sahip olduğu yüksek besin içeriğinden kaynaklanmaktadır. Özellikle de iz amino asitleri içerdiği, yağ ve şeker içeriği oldukça düşük olduğundan sağlıklı beslenmede önemli yer tutan kültür mantarı, yetiştiriciliği yapılan ülkelerdeki protein açı̆̆ının kapanmasına da büyük katkıda bulunacak gıdaların başında gelmektedir. Ülkemizde mantar yetiştiriciliği en çok küçük ev tipi üretim alanlarında yapılmakta olup, büyük modern işletmeler de kurularak her geçen gün önemi artmaktadır. Son yıllarda, mantar yetiştiriciliğinin üretimi ve verimi hızla artmakla birlikte, üreticiler bu verimi arttırmak amacıyla daha fazla koruyucu önlemler almakta ve yetiştirme koşullarının şartlarını uygun hale getirmek zorunda kalmaktadırlar. Mantar yetiştiriciliğinde, diğer tarım alanlarında olduğu gibi ürünlerde önemli verim kayıplarına neden olan bakteriyel, fungal ve viral kaynaklı pek çok hastalık etmeni sorun oluşturmaktadır. Bu çalışmada, yemeklik kültür mantarı yetiştiriciliğinde üreticilerin en çok karşılaştığı mikrobiyal hastalık etmenleri, bu hastalık etmenlerinin oluşturduğu hastalık belirtileri ve çözüm önerileri ele alınmıştır.
\end{abstract}

Anahtar Kelimeler: Yemeklik kültür mantarı, Agaricus bisporus, Fungal, Bakteriyel ve viral hastalıklar

\section{Common Observed Microbial Diseases in Edible Culture Mushrooms (Agaricus bisporus (J. Lge) Imbach)}

\begin{abstract}
The most commonly grown edible mushroom species is known as Agaricus bisporus. A. bisporus is one of the leading edible mushrooms consumed by people. The increase in the consumption of cultivated mushrooms is due to its high nutritional value. In particular, it contains essential amino acids and has lower fat and sugar compared to other foods and holds an important place in a healthy diet programme. Also mushroom production contributes to meeting the protein deficit in developing countries. In our country, most of the mushroom cultivation is made in small household rooms and also large modern mushroom production companies are increasing by time. In recent years, mushroom production and yield were increased by preventive methods applied by the producers. In the mushroom cultivation, which causes significant yield losses in such products as well as in other agricultural areas are bacterial, fungal and viral pathogens. This study focuses on symptoms of the microbial disease problems of Agaricus bisporus, caused by microbial pathogens resulted in economically important yield losses and recommendation for their efficient control.
\end{abstract}

Key Words: Edible mushroom, Agaricus bisporus, Fungal, Bacterial and viral diseases 


\section{Giriş}

Doğada bulunan yüzlerce mantar türleri arasında kültürü yapılan mantar türlerinin sayısı oldukça azdır. Dünya'da elde edilen verilere göre tüketilebilir yaklaşık 200 mantar türünden $25^{\prime} \mathrm{i}$ kültüre alınabilmiştir. Tüketildiği halde kültüre alınmaya çalışılan birçok mantar türü de bulunmaktadır. Yenilebilir mantarlardan yaklaşık \% 32'lik oranla bütün Dünya'da en fazla yetiştiriciliği yapılan tür beyaz şapkalı kültür mantarı (Agaricus bisporus (J. Lge) Imbach)'dır (Özbayram ve Savaşkan, 1983; Chang, 1999). Dünyada üretim olarak $A$. bisporus' $\mathrm{u}$, Lentinus edodes (meşe mantarı), Flamminula velutipes (enoki mantarı), Auricularia spp. (ağaç kulağı mantarı), Volvariella volvacea (saman mantarı), Pleurotus spp. (kayın veya istiridye mantarları), Tremella fuciformis (jöle mantarı) ve Pholiota nameko (nameko mantarı) izlemektedir (Beelman ve ark., 2004).

Dünyada 19. yüzyıldan beri kültürü yapılan yemeklik kültür mantarı üretimi özellikle de Avrupa ülkelerinde 1950'li yıllardan sonra giderek artan bir endüstri alanı haline gelmiştir. Dünya mantar üretiminde en büyük payla ilk sıralarda Çin, A.B.D, Fransa ve Hollanda yer almaktadırlar. Türkiye'de ise mantar üretimi 1960 'lı yıllarda küçük bir deneme ile başlamış, ancak ekonomik açıdan önemli ilk büyük işletmeler 1970'li yıllarda ortaya çıkmıştır. Türkiye'de hem kültür mantarı üretiminin geç başlaması, hem de üretimle ilgili bilgi ve teknolojinin yaygınlaştırılamamış olması, ayrıca modern tesislerin azlığı ve küçük ev tipi işletmelerin üretimde $\%$ 70-80 paya sahip olması bakımından mantar yetiştiriciliği iyi bir gelişme gösterememiştir (Özbayram ve Savaşkan, 1983; Bora ve ark., 1996; Basım 2004; Basım ve illkuçan, 2004).
Türkiye de kültür mantarı üretimi 2014 yılında 45.000 ton civarında olup yıllık kişi başına düşen mantar tüketim miktarı 579.2 gramdır. Kültür mantarı üretiminde lider konumundaki 5 il sırasıyla Antalya, Burdur, Konya, Kocaeli ve İzmir'dir. Bunları Denizli, Malatya ve Kütahya illeri izlemektedir (Anonim, 2015). Antalya ilinde 2004 yılında Türkiye kültür mantarı üretiminin \% 74'ü gerçekleşirken 2013 yılında toplam üretimin $\%$ 55'i gerçekleşmiştir. Antalya ili Korkuteli ilçesi Türkiye'nin kültür mantarı ve kompost üretim merkezi durumunda olup, 18.500 ton ile en fazla mantar üretiminin yapıldığı ilçedir (Eren ve Pekşen, 2016)

Ülkemizde üretimi yapılan ve en çok tüketilen kültür mantarı $A$. bisporus'dur. $A$. bisporus, B vitamini kompleksleri ve protein içeriği bakımından zengin olup toplam mantar ağırlığının \% 88-90 kadarını da bünyesindeki su oluşturmaktadır. Kültür mantarında yağ ve karbonhidrat oranı az miktarda bulunmaktadır. Mantar, besin içeriğindeki yağ miktarının yok denecek kadar az olması, içeriğinde bulunan karbonhidratlarının da sindirilememesi, kolesterolü azaltıcı özellikleri ile uzak doğu ülkelerinde birçok hastalığın tedavisinde kullanılmakta ve iyi bir besin kaynağı olarak önerilmektedir (Beelman ve ark., 2004). Birçok mantar türünün de endüstri, gıda, ve sağlık alanlarındaki kullanımları ve yararları yapılan çalışmalarla ortaya konulmuştur (Chang ve Miles, 2004).

Mantar yetiştiriciliğinde en önemli noktalardan birisi, sağlıklı, verimli ve pazar değeri yüksek ürün yetiştirmektir. Bu hususların yerine getirilebilmesi için mantar yetiştirirken belirli koşulların sağlanması ve yetiştiricilikte sorun oluşturan etkenlerin çözülmesi gerekmektedir. Bu sorunlar; hijyenik önlemlerin alınmaması, üretim materyallerinin istenildiği gibi olmaması, gelişim koşullarının uygun olmaması, 
hastalıklardan ve zararlılardan kaynaklanan etkilerin oluşturduğu sorunlardır. Mantar yetiştiriciliğinde ekonomik açıdan üreticiyi zor durumda bırakan hastalıklar, mantarın pazar değerini düşürdükleri gibi verim ve ürün kayıplarına neden olan fungal, bakteriyel ve viral hastalık etmenlerini de karşımıza çıkarmaktadır.

\section{Fungal Hastalıklar}

Yemeklik kültür mantarı üretim alanlarında yetiştiriciliği zorlaştıran fungusların bir bölümü rekabet fungusu, bir bölümü ise parazit funguslardır. Yaşadıkları ve görüldükleri ortam dikkate alındığında kompostta, örtü toprağında, hem kompostta hem de örtü toprağında görülen fungal hastalıklar olarak gözlenmektedir. Kültür mantarındaki fungal hastalık etmenlerini sınıflandırdı̆ı̆mızda; kompostta görülen fungal hastalıklar; sarı küf (Chrysosporium spp.), zeytin yeşili küfü (Chaetomium spp.), mürekkep şapka (Coprinus spp.); örtü toprağında görülen fungal hastalıklar; örümcek ağı (Cladobotryum dendroides), yaş kabarcık (Mycogone perniciosa), kuru kabarcık (Verticillium fungicola); örtü toprağı ve kompostta görülen fungal hastalıklar ise; kahverengi alçı (Papulospora byssina), beyaz alçı (Scopulariopsis fimicola), yalancı domalan
(Diehliomyces microspora) ve yeşil küf (Trichoderma spp.)' tür.

\section{Yaş Kabarcık Hastalığı (Mycogone perniciosa)}

Yemeklik kültür mantarı yetiştiriciliğinde çok sıklıkla rastlanan ve büyük zararlara yol açan yaş kabarcık hastalığına neden olan fungal hastalık etmeni Mycogone perniciosa'dır. 1888 yılından bu yana mantar yetiştiriciliğinde önemli ekonomik kayıplara yol açan ve mantarlarda, ciddi deformasyonlara neden olan bir hastalıktır. Yaş kabarcık hastalık etmeni yemeklik mantarlarda, ciddi şekil bozukluğuna neden olduğu için yemeklik mantarların pazar değerinin kaybetmesine yol açmaktadır (Dielemann-Van Zaayen, 1976). Hastalık etmeni, primordium formundaki mantarları enfekte ettiği zaman, mantarlar anormal şekilde gelişme göstermektedirler. Bu belirtiyi gösteren mantarlar şiddetli deformasyona uğramakta ve. deforme olmuş mantarlar birleşerek şekilsiz yığınlar gibi bir yumruk şeklinde gelişmektedirler (Şekil 1). Mantarlar normal büyüklüğe ulaştıktan sonra gerçekleşirse kalın sap oluşumu gözlenir. Hastalıklı mantar gövdesinin tamamı önce beyaz misellerle, daha sonra ise kahverengi misellerle kaplanarak çürüme meydana gelmektedir (Sharma ve Kumar, 2000). A. bisporus türleri ise bu hastalığa karşı oldukça hassastırlar (Umar ve ark., 2000).

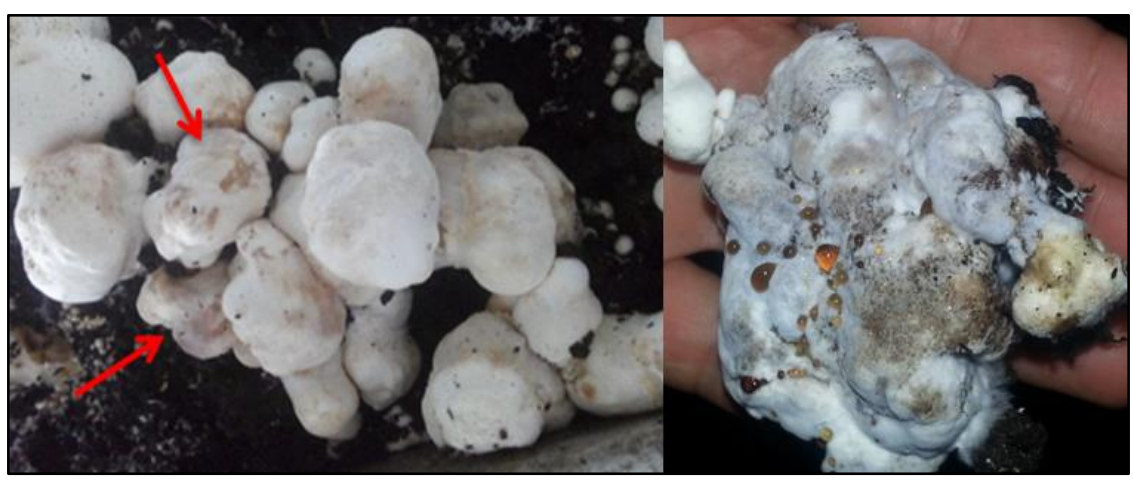

Şekil 1. Yemeklik kültür mantarındaki yaş kabarcık hastalığının belirtileri

Figure 1. Symptoms of wet bubble disease in edible culture mushroom 
Kuru Kabarcık Hastalığı (Verticillium
fungicola)

Kuru kabarcık hastalığı, yemeklik kültür mantarı yetiştiriciliğinde önemli kayıplara neden olan fungal hastalıklardan birisidir. Bu hastalığa neden olan hastalık etmeni Verticillium fungicola' dır (Wuest ve Bengston, 1982). Hastalık özellikle örtü toprağının serilmesinden sonra ortaya çıkarsa büyük oranda verim kayıplarına neden olmaktadır. Geç enfeksiyonda hastalıklı mantarların şapkasında açık kahverengi, yüzeysel ve düzensiz lekeler oluşmaktadır. Erken enfeksiyonda ise gelişmekte olan primordiumlarda şapka büyümesi bozulmakta ve taslaklar birleşerek bir top benzeri bir kütle oluşturmaktadır. Şiddetli enfeksiyonda ise şapka yapısında düzensiz oluşumlar görülmektedir (Şekil 2) (Wuest ve Bengston, 1982; Fletcher ve ark., 1989). Özellikle oda sıcaklığının $20^{\circ} \mathrm{C}^{\prime}$ nin üstünde çıkması hastalık etmeninin çok hızlı gelişerek kolonize olmasına neden olmaktadır. Mantar sinekleri, patojen sporlarını taşıyarak hastalı̆̆ı şiddetini ve yoğunluğunu arttırmaktadırlar. (Van Griensven, 1988).

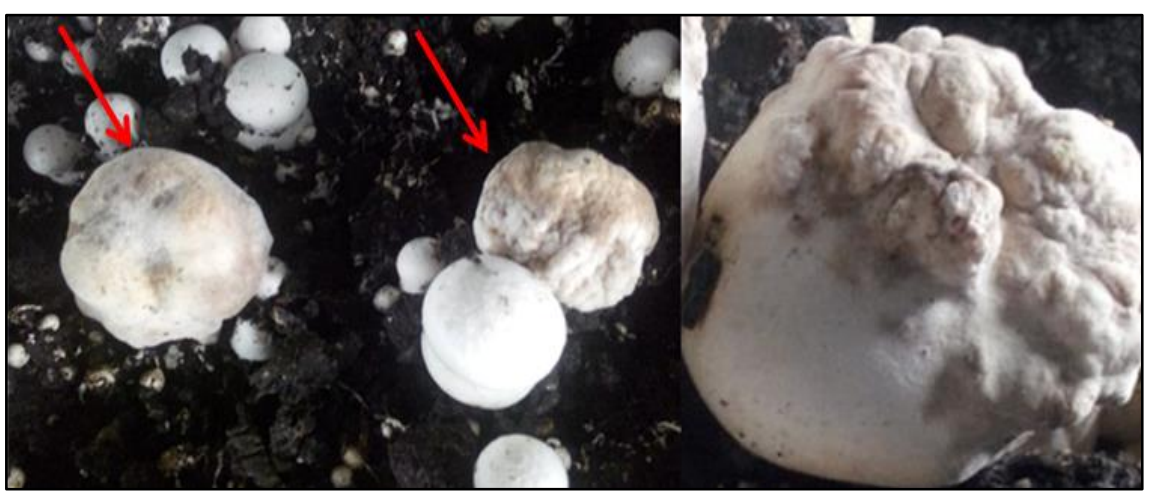

Şekil 2. Kültür mantarındaki kuru kabarcık hastalığının belirtileri

Figure 2. Symptoms of dry bubble disease in edible culture mushroom

\section{Örümcek Ağı Hastalığı (Cladobotryum dendroides)}

Örümcek ağı hastalığı, mantar yetiştiriciliğinde önemli ürün kayıplarına neden olan hastalıklardan birisidir ve örümcek ağı hastalığına Cladobotryum dendroides etmeni neden olmaktadır (Howard ve ark., 1994; Grogan ve Gaze, 2000). Genellikle hasattan sonra kesilmiş ve üretim alanı üzerinde bırakılmış mantar kalıntıları ile ölü mantar gövdelerinden kaynaklanan bir hastalıktır. En karakteristik belirtisi, örtü toprağı ile mantarlar taslakları üzerinde yoğun bir ağ görünümü oluşturmasıdır (Fletcher ve ark., 1989). Örtü toprağı üzerinde gelişen tüy halindeki miseller başlangıçta beyaz renktedir (Şekil 3) (Howard ve ark., 1994). Örümcek ağı hastalık etmeni ile enfekteli mantarlar sarımsı kahverengine döner, bükülür ve şiddetli enfeksiyonda mantarlar komposttan ayrılarak düşer. Hastalığın etkinliği, mantar gelişme sırasında hızlı bir yayılış göstererek örtü toprağını ve mantarların üzerini örterek yıkıcı bir etkiye neden olmasıdır. Hastalık etmenine ait sporlar hava, su, hastalıklı materyal ve toplayıcılar tarafından üretim alanına yayılmaktadır (Fletcher ve ark., 1989; Howard ve ark., 1994). 


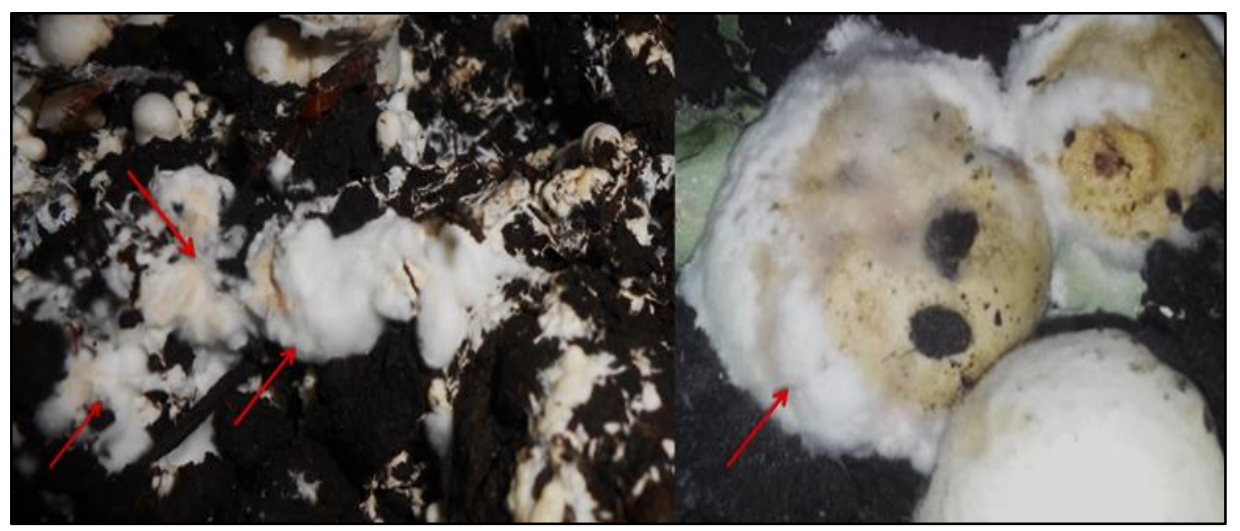

Şekil 3. Yemeklik kültür mantarındaki örümcek ağı hastalığının belirtileri

Figure 3. Symptoms of cobweb disease in edible culture mushroom

Yeşil Küf Hastalığı ( Trichoderma sp.)

Yeşil küf hastalığı; koyu, bol miktarlarda yeşil spor üretir ve bu yüzden de adı yeşil küf olarak karakterize edilmektedir (Şekil 4) (Fletcher ve ark., 1989). Mantar yetiştiriciliğinde sorunlu Trichoderma türleri T. harzianum Rifai, T. koningii Oudem ve $T$. viride (Pers.) Fr.'dir (Howard ve ark., 1994). A. bisporus'un en hassas olduğu yeşil küf hastalık etmeni ise T. harzianum'dur (Savoie ve Mata, 2003). Bu hastalık daha çok mantar yetiştiriciliğinde hijyenik önlemlere dikkat edilmeyen eski işletmelerde görülmektedir. Temiz olmayan kasaların steril edilmeden kullanılması, kesilen mantar saplarının kalıntılarının üretim alanından uzaklaştırılmaması sonucu örtü toprağı yüzeyinde ve gelişen mantarlar arasında beyaz pamuksu miseller şeklinde ortaya çıkmaktadır (Fletcher ve ark., 1989; Howard ve ark., 1994). Optimum gelişme sıcaklıkları $22 \circ \mathrm{C}$ ile $26 \circ \mathrm{C}$ arasında değişmektedir. Mantar üretim alanında yeşil küf miselleri daha hızlı geliştiği için kültür mantarının misellerinin gelişmesini durdurarak verimde önemli kayıplara neden olmaktadır (Fletcher ve ark., 1989).

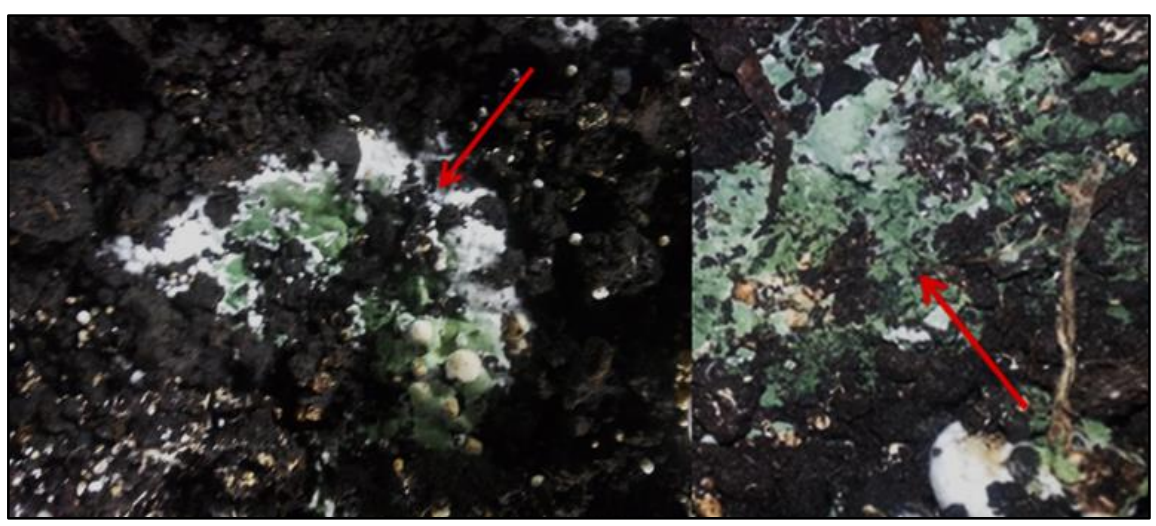

Şekil 4. Yenilebilir kültür mantarındaki yeşil küf hastalık belirtileri

Figure 4. Symptoms of green mold disease in edible culture mushroom

Mürekkep Şapka Hastalığı (Coprinus spp.)

Mürekkep şapka mantarı olarak

isimlendirilen hastalığa Coprinus spp. etmenleri neden olmaktadır (Wuest, 1990). Mantarların misel gelişme döneminde fungusun gri renkli miselleri gelişirken, bu 
durum komposttaki amonyum fazlalığından kaynaklanmaktadır. Kompost iyi fermente olmamış ve olgunlaşmasını tamamlamamışsa, pastörizasyon süresi kısa tutulmuşsa, mantar misellerinin ön gelişme döneminde gri renkli amonyak mantarları gelişmeye başlar (Van Griensven, 1988). Başlangıçta hızlı gelişen beyaz miseller ortaya çıkmakta, daha sonra uzun kırılabilir saplı çan şeklinde mantarlar oluşmaktadır. Krem renkli şapkalar daha sonra mavi-siyah renge dönüşmekte, genellikle pullar ile kaplanmakta ve bu şapkalar açılarak mürekkep renginde sıvı salgılamaktadır. Hastalık belirtisi görüldükten birkaç gün sonra mantarlar çürümekte ve siyah sümüksü bir hale dönüşmektedir (Şekil 5) (Wuest, 1990).

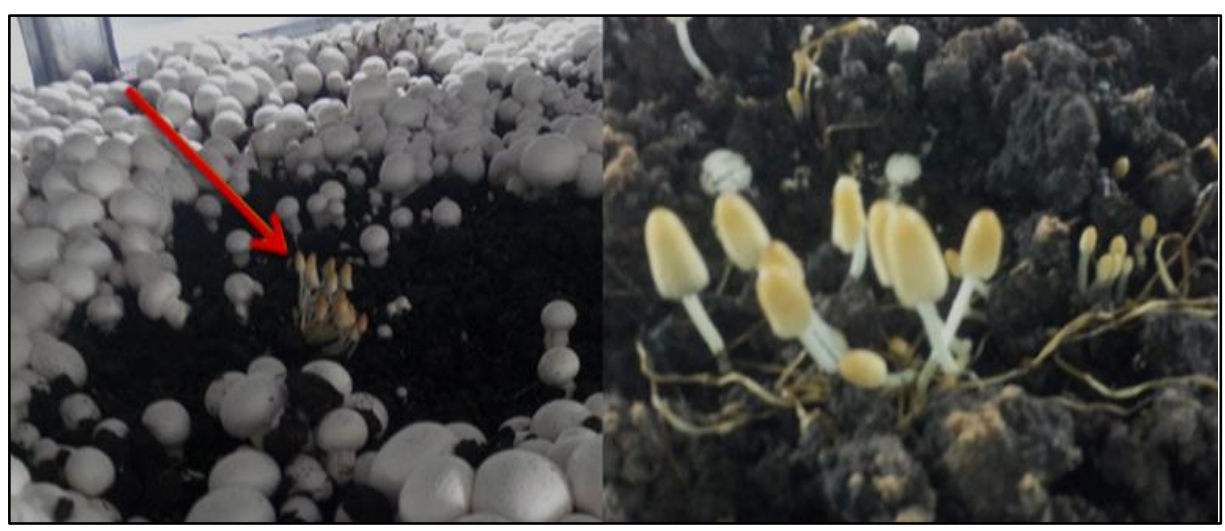

Şekil 5. Yenilebilir kültür mantarındaki mürekkep şapka hastalığının belirtileri

Figure 5. Symptoms of ink cap disease in edible culture mushroom

\section{Alçı Hastalığı (Scopulariopsis fimicola, Papulaspora byssina)}

Mantar yetiştiriciliğinde kompostta görülen alçı hastalığının iki etmeni vardır. Bunlar beyaz alçı hastalı̆̆ı etmeni Scopulariopsis fimicola ve kahverengi alçı hastalığı etmeni Papulaspora byssina'dır (Wuest ve Bengston, 1982).

Beyaz alçı hastalığı, örtü toprağının üst kısmında ve kompostun dış kısmında sık sık ortaya çıkan bir hastalıktır. Hastalığın en karakteristik belirtisi, başlangıçta beyaz ve tüysü gelişim göstermesi, daha sonra ise tamamen geliştiği ortamı kaplayarak beyaz bir tozla kaplanmış bir görüntü oluşturmasıdır (Şekil 6a). Hastalığın oluştuğu kısmın altına bakıldığında da kompost içinde beyaz alçı hastalığı misellerinin derinlere yayıldı̆̆ı görülmektedir. Bu kısımlarda enfeksiyon yoğunluğu az ise misel gelişimi yavaşlar, enfeksiyon şiddeti yoğun ise mantar misellerinin gelişimi tamamen durur. Enfeksiyona uğrayan kompost son dönemde siyahlaşır ve ortama yoğun çürük kokusu yayılır (Fletcher ve ark., 1989).

Kahverengi alçı hastalığı genelde mantar tesislerinde sıklıkla görülür, fakat beyaz alçı hastalığına göre daha az önemlidir. Başlangıçta kompostun ve daha sonra örtü toprağının üzerinde beyaz miseller oluşur. Bu misellerin orta kısmından miseller koyulaşarak kahverengine dönüşür ve enfeksiyon yoğunlaştığında tamamen kompostun etrafı kahverengi bir örtüyle kaplanır (Şekil 6b) (Fletcher ve ark., 1989).

Her iki alçı hastalığı da şiddetli enfeksiyonlarda misel gelişimini durdurucu etkiye neden oldukları için mantar veriminde önemli azalmalara yol açmaktadır (Howard ve ark., 1994; Fletcher ve ark., 1989). Bu hastalıkların önceden teşhisi zor olduğu için 
kullanılan kompostların iyi hazırlanmış olması gerekmektedir (Van Griensven, 1988).

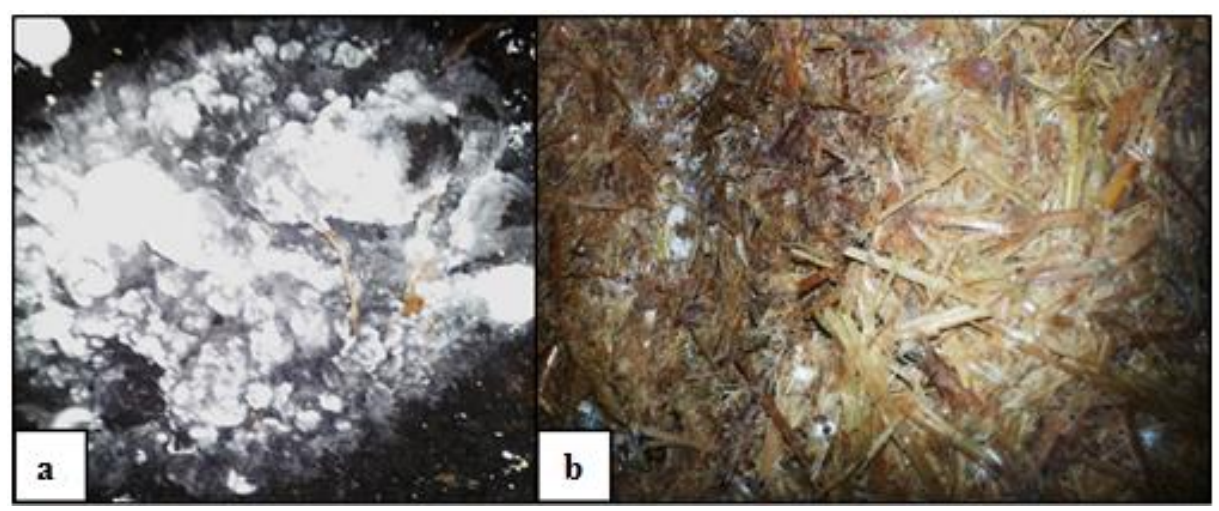

Şekil 6. Yenilebilir kültür mantarındaki alçı hastalığı belirtileri a: Beyaz alçı hastalığı, b: Kahverengi alçı hastalı̆̆ı

Figure 6. Symptoms of plaster mold disease in edible culture mushroom a: White plaster mold disease, $b$ :. Brown plaster mold disease

Yalancı Domalan Hastalığı (Diehliomyces microspora)

Domalan hastalığı veya yalancı domalan hastalığı Diehliomyces microspora fungal patojeninden kaynaklanmaktadır (Wuest ve Bengston, 1982). Domalan sık sık ticari mantar üretiminde karşılaşılan ve önemli verim kayıplarına neden olan bir hastalıktır (Howard ve ark., 1994). Bu hastalığı oluşturan miseller kompostun iç kısmında gelişme gösterir. Miselleri sarımsı beyaz renkte ve kalın ipliksi formdadır. Daha sonraları bu miseller örtü toprağı içine ve üzerine yerleşerek düzensiz şekilli mantar yapıları oluştururlar. Yalancı domalan hastalığı mantar misellerinin gelişmesini durdurmaktadır. Genç yalancı domalan mantarları örtü toprağı içinde ve üzerinde geliştiği zaman deforme olmuş küçük mantarlara benzeyen yapılar şeklinde ortaya çıkmaktadır (Şekil 7). Misellerin yığın olarak bir araya gelmesinden oluşan yalancı domalanlar başlangıçta sarımsı beyaz renkte ve daha sonra kahverengiye dönüşen mantar benzeri deforme olmuş yapılar oluşturmaktadır (Fletcher ve ark., 1989; Howard ve ark., 1994).

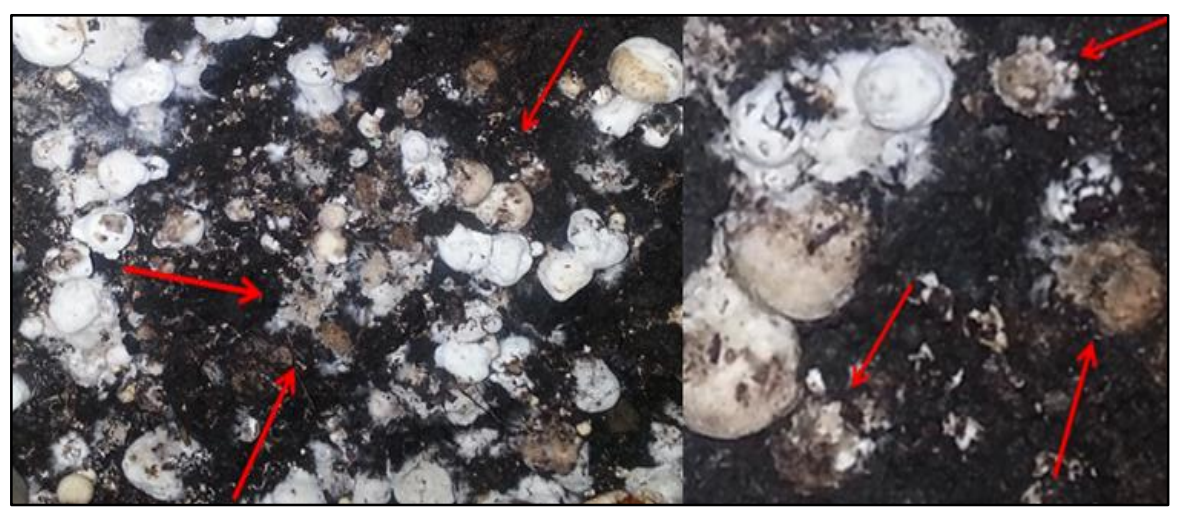

Şekil 7. Yenilebilir kültür mantarındaki yalancı domalan hastalık belirtileri

Figure 7. Symptoms of false truffle disease in edible culture mushroom 
Yeşil Zeytin Küfü Hastalığı (Chaetomium globosum)

Zeytin yeşili küfü hastalığı uygun koşullarda hazırlanmayan ve iyi pastörize edilmeyen kompostun bir göstergesidir (Van Griensven, 1988). Yeni pastörize uygulaması yapılan kompost içinde ve kompost üzerinde beyaz tüy gibi misel parçacıkları şeklinde belirti göstermektedir. Hastalık belirtisi gösteren beyaz tüy yapısı birkaç gün sonra tamamen kaybolarak koyu zeytin yeşili veya siyaha yakın spor kümeleri oluşturmaktadır (Howard ve ark., 1994). Kompostta görülen küf, kompost üzerinde gelişmeye devam ederek etrafa nemli küf kokusu saçmaktadır. Hastalık etmeni ile bulaşık komposta ilave edilen misellerin gelişimi çok az veya hiç gerçekleşmemektedir (Wuest ve Bengston, 1982). Yeşil zeytin küfü hastalığı; yüksek sıcaklıkta $\quad\left(60^{\circ} \mathrm{C}-62^{\circ} \mathrm{C}\right)$ uzun süre pastörizasyonun yapılması, kompostun havalandırma aşamalarının yapılmaması, kompostun ikinci fermantasyon aşamasının çok kısa tutulması, kompostta yüksek oranda amonyağın kalması gibi faktörler hastalığın gelişmesi için uygun koşulları oluşturmaktadır (Van Griensven, 1988).

\section{Sarı Küf Hastalığı (Chrysosporium spp.)}

Hastalık genellikle kompost ile örtü toprağı arasındaki kısımda başlangıçta sarı misel benekleri şeklinde görülür. $\mathrm{Bu}$ misel toplulukları 1-2 cm büyüklüğüne kadar ulaşmaktadırlar. Bazen bu misel topluluklarının bir araya gelmesi ile çok sayıda sarı yığınlar da oluşmaktadır. Mantarların hasadını takip eden birinci veya ikinci haftadan itibaren hijyenik önlemlerin alınmaması durumunda, çok sayıda ölü mantar dokuları oluşur ve verim bir anda düşmektedir. Bu durum, sarı küfün yaptığı en önemli zarar şeklidir (Wuest ve Bengston, 1982; Howard ve ark., 1994).

\section{Bakteriyel Hastalıklar}

Yemeklik kültür mantar yetiştiriciliğinde karşılaşılan en yaygın bakteriyel hastalıklardan birisi Pseudomonas tolaasii'nin neden olduğu bakteriyel kahverengi benek hastalığı olup, kültür mantarında önemli zararlara neden olmaktadır (Fidan ve ark., 1999). Hastalık etmeni olan bakteri çoğunlukla örtü toprağında bulunurken, hastalık belirtileri, kültür mantarının şapkalarında başlangıçta krem renkli, küçük noktalar ya da lekeler görünümünde ortaya çıkmaktadır. Enfeksiyon şiddetlendiğinde ise leke hızla büyüyerek ve rengi de koyu kahverengine dönerek henüz primordium halinde olan mantar topluluklarının rengini kahverengileştirmekte ve mantarlar ölmektedir. Bakteriyel lekelerin bulunduğu kısımlarda şapkada içeri doğru 1-2 mm kadar çukurlaşmalar görülmektedir (Şekil 8). Şapkadaki gibi benzer belirtilere mantarın sap kısmında da rastlanabilmektedir. Mantar şapkalarında, hasat sırasında gözden kaçan küçük benekler, pazara sunulduğunda, marketlerde tüketime sunulduğunda, mantarda gelişerek şapka üzerinde kahverengi lekelenmelere yol açarak mantarın tüketici tarafından alım kalitesini düşürmektedirler. Şiddetli enfeksiyonlarda hastalık, hasat odasında primodiumların ve genç mantarların toplu halde ölümüne neden olarak, ekonomik seviyede verim düşüşlerine de neden olmaktadır. Mantarlarda hasat dönemine yakın yapılan sulamalardan sonra en az birkaç saat kadar şapka yüzeyinin nemli kalması ve oda sıcaklığının da $20^{\circ} \mathrm{C}$ seviyesinde olması hastalığın oluşması için yeterlidir. Enfeksiyon oluşumundan bir kaç saat sonra ise mantar şapkalarında benekler görülmeye başlar (Bora ve ark., 1996). 


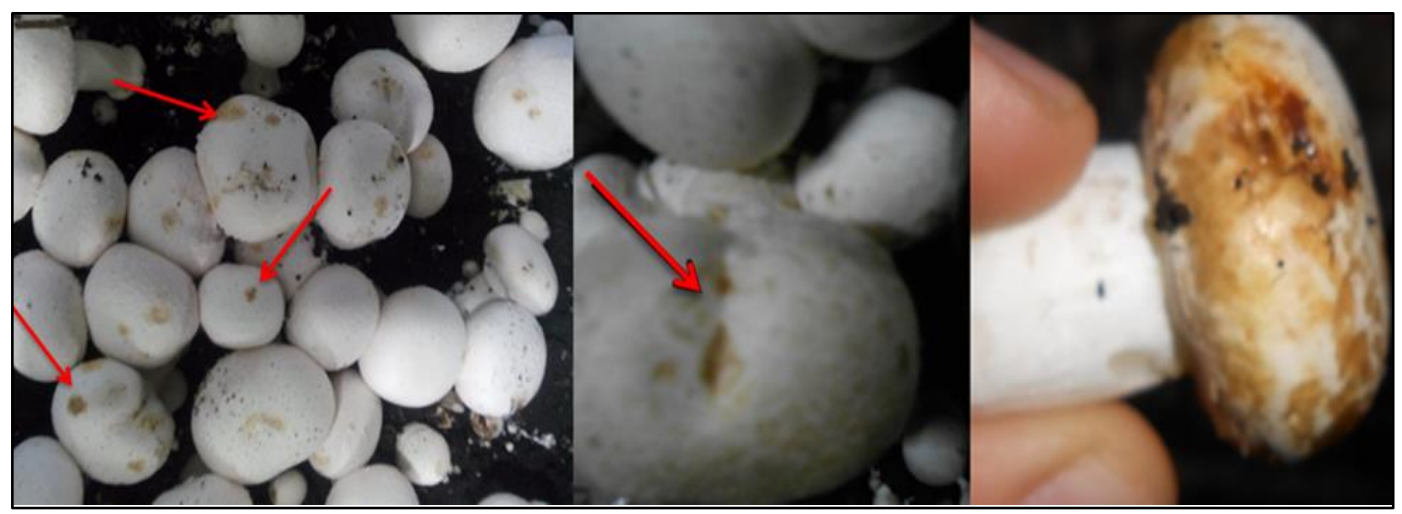

Şekil 8. Yenilebilir kültür mantarında bakteriyel kahverengi benek hastalığının belirtisi

Figure 8. Symptoms of bacterial brown blotch disease in edible culture mushroom

\section{Viral Hastalıklar}

Yemeklik kültür mantarları üretiminde sorun oluşturan birçok viral hastalık etmeni bulunmaktadır. Kültür mantarları genellikle aynı anda birden fazla virüs tarafından enfekte edilmektedir (Goodin ve ark., 1992; Romaine ve ark., 1993; Romaine ve Schlagnhaufer, 1995). Viral hastalıkların verdikleri ekonomik kayıplar bakımından üretim alanında günümüzde en çok zarara neden olan mantar virüsleri La France Isometric Virüs (LIV) ve Mushroom Virüs $X$ (MVX) virüslerdir. Bu virüslerden LIV'ın sebep olduğu $X$ hastalığı sulu sap oluşumu, geriye doğru ölüm ve kahverengileşme hastalığı adlarıyla da bilinen La France hastalığı olup $A$. bisporus'un en çok etkilendiği viral hastalıklardan birisidir. La France hastalığının kültür mantarlarında oluşturduğu belirtiler; miselin örtü toprağını sarmaması veya misel örtü toprağını zayıf bir şekilde sarması ve bu etkiden dolayı saran misellerin ölmesi şeklindedir. Böyle alanlarda primordiumlar oluşmadığından ve bu alanlarda mantar gelişimi olmadığı için boş kalmaktadır, dolayısıyla da üretim gerçekleşemediği için büyük verim kayıplarına neden olmaktadır. Boş alanların etrafında sıkışık yığın şeklinde mantar gelişimi görülmekte ve bunlar da çok erken olgunlaştıkları için verimsiz olmaktadırlar. Illk flaşta baş görünüşü geciktiğinden ve primordiumlar toprağın altında oluştuğundan mantarların şapkaları örtü toprağının üstüne çıktıkları anda hemen açılmaktadır. Hastalıklı mantarların sap kısımları normalden daha uzun, şapka da normalden daha küçük kaldığı için mantar şekli davul tokmağı görüntüsünde olmaktadır. Bazen saplar kalınlaşarak şapkanın çapıyla aynı olmaktadır. Genelde lamel zarı sapın en kalın kısmında iken, hastalıkla enfekteliyken genellikle normalden daha aşă̆ıda lamel oluşumu gözlenmektedir. Şapkalar sapa bağlandığı kısımdan yana doğru eğilmektedirler. Virüs spor çimlenmesine etki ettiği için hastalıklı mantarlar sağıklı olanlardan daha az sayıda spor üretmektedir. Hastalıklı mantarlar çok çabuk komposttan ayrılmaktadır. Saplar süngerimsi, sulanmış ve uzunlamasına çizgili şekilde görülebilirler. Oda sıcaklı̆̆ı yükseldikçe de belirtiler şiddetlenmektedir. Şiddetli enfeksiyonlarda viral hastalık mantarda oldukça fazla ürün kaybına yol açabilmektedir (Şekil 9a) (Van Zaayen, 1972; Van Zaayen, 1979; Fletcher ve ark., 1989).

Yemeklik kültür mantarlarında 1996 yılında İngiltere'de üretim alanlarında primordium çıkısını baskılayan LIV'den farklı bir virüs daha tespit edilmiş ve $M V X$ (Mushroom Virus $\mathrm{X}$ ) olarak adlandırılmıştır 
(Grogan ve ark., 2003; Adie ve ark., 2004). Mantar üretiminde son dönemlerde ortaya çıkan MVX'in neden olduğu hastalık belirtileri başların gelişmemesi ve bu etkinin sonucunda kompost üzerinde boş alanların görülmesidir (Şekil 9b). Bazı durumlarda başlar gecikmeli de olsa gelişirler, fakat bu sefer de üretim alanı üzerindeki mantarlarda gelişim seviyeleri bakımından farklılıklar ortaya çıkar ve bu da hasadın gecikmesine neden olmaktadır. Geç gelişen hastalıklı mantarların şapkaları olduğundan daha da erken açılmaktadır. Bu tip mantarlar, üretim alanlarında normal olarak gelişirken, hasattan sonra şapkalar bir anda açılır ve dolayısıyla ürünün kalitesinde düşüşler gerçekleşir. Bu viral hastalığın en şiddetli belirtisi, lamel zar yapısının hiç oluşamaması durumudur ki bu hastalık belirtisi genellikle 2. flaşta görülür. Bu nedenle, hastalıklı mantarlarda spor oluşumu gözlenmez. Hastalıkla enfekteli mantarlar sağlıklı beyaz rengini kaybeder ve kahverengi gelişirler (Şekil 9b). Kahverengileşmiş mantarlar üretim kasalarında görüldüğü gibi depo odalarındaki mantarlarda da ortaya çıkabilmektedir. Kahverengi oluşum, pazar değerini ve ürünün kalitesini düşürmektedir. Viral hastalıklar, mantarlarda şekil bozukluklarına neden olduğu için verim kayıpları \% 50-80' ye kadar ulaşabilmektedir (Grogan ve ark., 2003).

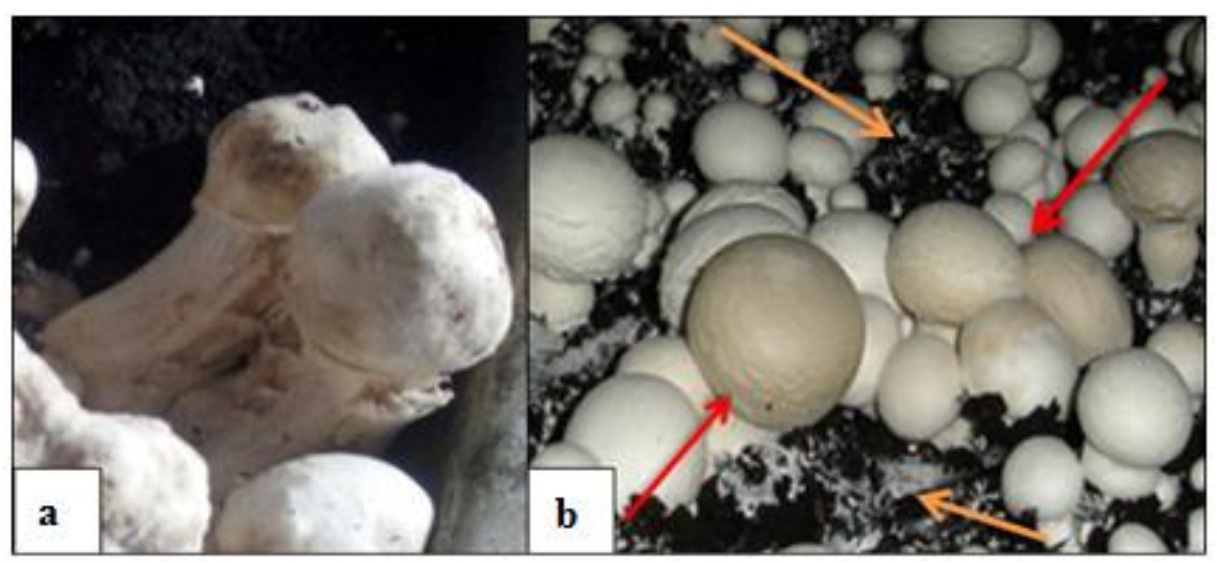

Şekil 9. Yenilebilir kültür mantarındaki viral hastalıkların belirtileri a: La France hastalığı, b: Mushroom virus $\mathrm{X}$ hastalığı

Figure 9. Symptoms of viral diseases in edible culture mushroom a: La France disease, $b$ : Mushroom virus $X$ disease

\section{Sonuçlar}

Yemeklik kültür mantarı üretiminde, üretimi sınırlayan hastalıkların ortaya çıkısından sonra hastalıklarla mücadele son derece güç olduğu için yapılacak en uygun mücadele koruyucu önlemlere, yani hijyenik önlemlere ağırlık vermektir. Koruyucu önlemler olarak mantar yetiştiriciliğinde ana materyal olan misel, kompost ve örtü toprağının kullanımında hijyenik önlemlerin esas alınmasıdır. Misel üretim aşamasında, misel aşılama odalarının uygun steril koşullarına göre dizayn edilmesi ve teknik elemanların steril koşullara dikkat etmesi gerekmektedir.

Mantar yetiştiriciliğinde önemli ana materyallerden biri olan kompost, mikrobiyal hastalıkların bazılarının ana kaynağını oluşturmaktadır. Kompostun iyice olgunlaştırılmaması, iyi havalandırılmaması ve kompostun uygun sıcaklıklarda pastörize 
edilmemesi gibi faktörler hastalıkların oluşumuna zemin hazırlamaktadır. Bu nedenle kompostun uygun koşullara göre hazırlanması bazı hastalıkların oluşumunu engelleyecektir. Bunun yanında kompostun bekletildiği kompost platformlarının beton zeminle kaplı olması ve çeşitli kimyasallarla dezenfeksiyon yapılması gerekmektedir. Örtü toprağı kaynaklı oluşan hastalıkların önlenmesi için örtü toprağı atılmadan önce dezenfekte edilmesi hastalık oluşumunu engelleyebilmektedir.

Mantar üretiminde üreticilerin, her yetiştirme dönemi sonunda üretim odalarını yeni döneme hazırlamak için formaldehit ile dezenfekte etmesi, duvarları, pencereleri, rafları, zemin ve duvarları, çatlak ve deformeleri kontrol ederek yenilemesi gerekmektedir. Dezenfekte edilen odalar en az 24 saat kapalı tutulmalıdır. Odalar doldurulmadan önce hava girişlerine spor filtreleri (HEPA filtreler, $2 \mu$ çapında filtreler veya $2 \mathrm{~cm}$ kalınlıktaki cam yünü) yerleştirilmelidir. Yetiştirme zamanında bu filtreler üretim odasındaki koşullara göre üretim boyunca 1-2 kez değiştirilmelidir. Odaların ayrı bir girişi olmalı ve her odaya girişte elbise, ayakkabı, merdiven, kova, kesim bıçağı, üretim kasaları gibi ekipmanlar her oda için ayrı ayrı olmalıdır. Çünkü hastalıkı odalarda kullanılan ekipmanlar ile diğer sağlıklı üretim odalarına hastalıkların taşınmasında etken faktör olmaktadırlar. Koridorlarlar \% 2 ticari formaldehit ile ilaçlanmalıdır. Plastik tek kullanımlık eldiven kullanımı yaygınlaştırılmalı ve sık sık etkili bir dezenfektan ile eller temizlenmelidir.

Ayrıca bazı hastalıkların taşıyıcısı olan sineklerle de insektisitlerin kullanımı ile iyi bir sinek mücadelesi yapılmalıdır. Mantarların ön gelişme aşaması sırasında mantar sineklerine karşı kompostun üzeri bir kağıt veya ince bir plastik örtü ile kapatılmalıdır. Kağıtlar haftada iki kez formaldehit ile ıslatılmalıdır. Bu işlem, topraklamaya birkaç gün kalana kadar tekrarlanmalıdır. Üretim sırasında hastalıklı kısımların üretim odalarından uzaklaştırılması gerekmektedir. Hastalıklı materyaller üretim alanının dışında imha edilmelidir. Sporların dağıImasını önlemek için hasat işlemleri tüm mantarlar açılmadan önce toplanmalıdır. Önce sağlıklı mantarlar, daha sonra ise hastalıklı olan mantarlar toplanmalıdır.

Yemeklik kültür mantarı üretim odalarında birkaç fungal hastalığın kontrolünde kimyasal ilaç kullanımı en son başvurulan yöntem olmalı ve insan sağlığı açısından kalıntı süresi kısa, bekleme süresi az olan ruhsatlı preparatlara yer verilmelidir. Çünkü yemeklik mantarlara atılan ilaçların çoğu etki süresi uzun ve sistemik etkili ilaçlar olup kalıntı bırakabilmektedir (Basım ve Basım, 2008, Basım ve Basım, 2012a). Bu durum da, insan sağlığı açısından zararlı bir boyutta olup insanlarda kanser gibi hastalıklara zemin hazırlayabilmektedir. Bunun için kimyasal mücadeleye alternatif olabilecek biyolojik mücadele yöntemlerinin de zaman zaman kullanılması fazla ilaç kullanımının önüne geçebilecektir. Türkiye'de ümitvar biyolojik mücadele çalışmaları bulunmaktadır (Özaktan ve Bora, 1994; Gezen, 2003; Basım ve Basım, 2012b; Basım ve Basım, 2012c). Dünya'da biyolojik mücadele çalışmalarında antagonist bakteriler yemeklik kültür mantarında görülen hastalıklara karşı başarıyla kullanılmaktadır (Kosanovic ve ark.,2013; Tajalipour ve ark., 2014; Liu ve ark., 2015; Mohammad ve Sabaa, 2015; Potocnic ve ark., 2015; Mehrparvar ve ark., 2016). Bu nedenlerle biyolojik mücadele yöntem ve preparatlarının geliştirilmesi ile ilgili çalışmalara öncelik ve destek verilmelidir. Bakteriyel hastalıklara karşı ise taslak oluşumundan sonra sulamaya dikkat edilmeli, şapkalarda su birikintisine izin verilmemeli ve 
örtü toprağı serilmesiyle mantar yataklarına sulama suyuyla birlikte klorak (\% 10 çamaşır suyu) () uygulanması önerilmektedir. Fakat bu uygulamanın mantar veriminde düşüşlere ve mantarlarda kahverengi lekelere neden olduğu gözlenmiştir. Bu nedenle yetiştiricilikte insan sağlığı açısından düşünülerek hijyenik önlemlere daha çok önem verilmelidir. Üreticiler, hastalık ve zararlılar konusunda bilinçlendirilmeli, hastalık ve zararlılara karşı yapılacak olan mücadelede çevreye ve insan sağlığına daha az zararı olan, çevreye duyarlı özellikle de biyolojik mücadele ajanlarına ağırlık vererek mücadelenin yapılması konusunda eğitimden geçirilmelidirler.

\section{Kaynaklar}

Adie B., Choi I., Soares A., Holcroft S., Eastwood D., Mead A., Grogan H., Kerrigan R., Challen M., Mills P., 2004. MVX disease and doublestranded RNA elements in Agaricus bisporus. Proceedings of the XVIth International Congress on the Science and Cultivation of Edible and Medicinal Fungi. USA.

Anonim, 2015. Türkiye İstatistik Kurumu. Bitkisel Üretim İstatistikleri. www.tuik.gov.tr

Basım E., 2004. Antalya ili Korkuteli ilçesi kültür mantarı (Agaricus bisporus) üretim alanlarında ortaya çıkan fitopatolojik problemler ve çözüm önerileri. Türkiye VII. Yemeklik Mantar Kongresi, 143-147.

Basım E., Illkuçan M., 2004. Antalya ili Korkuteli ilçesinde kültür mantarında (Agaricus bisporus) tespit edilen fungal patojen Mycogone perniciosa' nın tanımı. Türkiye VII. Yemeklik Mantar Kongresi, 148-150.

Basım E., Basım H., 2008. Antalya ili Korkuteli ilçesinde üretilen kültür mantarlarında (Agaricus bisporus) GC/MSD ile pestisid kalıntılarının araştırılması. Türkiye 8 . Yemeklik Mantar Kongresi, Kocaeli, s. 26.

Basım E., Basım H., 2012a. GC/MSD ile Antalya ili Korkuteli ilçesinde üretimi yapılan kültür mantarı (Agaricus bisporus (Lange) Sing) ve kayın mantarındaki (Pleurotus ostreatus (Jacq.ex.Fr.) P.Kumm. pestisit kalıntılarının araştırılması. IX. Türkiye Yemeklik Mantar Kongresi, Denizli, s. 11.

Basım E., Basım H., 2012b. Kültür mantarında (Agaricus bisporus (Lange) Sing) görülen yaş kabarcık (Mycogene perniciosa (Magnus) Delacr.) hastalığına karşı farklı uçucu yağların antifungal etkilerinin araştırılması. IX. Türkiye Yemeklik Mantar Kongresi, Denizli, s. 62.

Basım E., Basım H., 2012c. Kültür mantarında (Agaricus bisporus (Lange) Sing) görülen kuru kabarcık (Verticillium fungicola (Preuss) Hassebr) hastalığına karşı gül (Rosa damascena Mill.), tarçın (Cinnamomum zeylanicum Blume) ve ökaliptus (Eucalyptus camaldulensis Dehn.) uçucu yağlarının antifungal etkilerinin araştırılması. IX. Türkiye Yemeklik Mantar Kongresi, Denizli, s. 61.

Beelman R.B., Royse D.J., Chikthimmah N., 2004. Bioactive components in button mushroom Agaricus bisporus (J. Lge) Imbach (Agaricomycetideae) of nutritional, medicinal, and biological importance. International Journal of Medicinal Mushrooms, 5: 321-327.

Bora T., Toros S., Özaktan H., 1996. Kültür mantarı hastalıkları, zararlıları ve savaşımı. Afa Matbaacilık, İstanbul, s. 137.

Chang S.T., 1999. World production of edible and medicinal mushrooms in 1997 with emphasis on Lentinus edodes (Berk.) Sing. in China. International Journal of Medicinal Mushrooms, 1: 291-300.

Chang S.T., Miles P.G., 2004. Mushrooms: cultivation, nutritional value, medicinal effect, and environmental impact, Second Edition, CRC Press, pp. 480.

Dielemann-Van Zaayen A., 1976. Diseases and pests of mushrooms. III. Fungus diseases. 1. Literature and research. Bedrijfsontwikkeling 7(12): 933-943.

Eren E., Pekşen A., 2016. Türkiye' de Kültür Mantarı Sektörünün Durumu ve Geleceğine Bakış. Türk Tarım-Gıda Bilim ve Teknoloji Dergisi, 4(3):189-196.

Fidan Ü., Bora T., Özaktan H. ve Gümüş M., 1999. Türkiye'de önemli kültür mantarı üretim merkezlerinde virüs ve ıslak kabarcık (Mycogene perniciosa) hastalıkları üzerinde araştırmalar. Bornova Zirai Mücadele Araştırma Enstitüsü/Bornova/izmir.

Fletcher J.T., White P.F., Gaze R.H., 1989. Mushrooms: Pest and disease control. 2. Edition. Intercept. Andover, Hants, pp. 174. 
Gezen M., 2003. Kültür mantarında bakteriyel benek (Pseudomonas tolaasii) hastalığının biyolojik kontrolünde antagonistlerin kritik konsantrasyonlarının saptanması üzerine bir çalışma. Ege Üniversitesi.

Goodin M.M., Schlagnhaufer B., Romaine C.P., 1992. Encapsidation of the La France disease-specific double stranded RNAs in $36 \mathrm{~nm}$ isometric virus like particles. Phytopathology, 82: 285-290.

Grogan H.M., Gaze R.H., 2000. Fungicide resistance among Cladobotryum spp. causal agents of cob web disease of the edible mushroom Agaricus bisporus. Mycological Research, 104(3): 357-364.

Grogan H.M., Adie B.A.T., Gaze R.H., Challen M.P., Mills P.R., 2003. Double-stranded RNA elements associated with the MVX Disease of Agaricus bisporus. Mycological Research, 107: 147-154.

Howard R.J., Garland J.A., Seaman W.L., 1994. Diseases and Pests of Vegetable Crops in Canada. Mushroom Chapter 26, The Canadian Phytopathological Society, Canada.

Kosanovic D., Potocnik I., Duduk B., Vukojevic J., Stajic M., Rekanovic E., Milijasevic-Marcic S., 2013. Trichoderma species on Agaricus bisporus farms in Serbia and their biocontrol. Association of Applied Biologists, 163: 218-230.

Liu C., Sheng J., Chen L., Zheng Y., Lee W.Y.D., Yang Y., Xu M., Shen L., 2015. Biocontrol activity of Bacillus subtilis isolated from Agaricus bisporus mushroom compost against pathogenic fungi. Journal of Agricultural and Food Chemistry, 63: 6009-6018.

Mehrparvara M., Goltapeha M.E., Safaiea N., Ashkanib S., Hedesh R.M., 2016. Antifungal activity of essential oils against mycelial growth of Lecanicillium fungicola var. fungicola and Agaricus bisporus. Industrial Crops and Products, pp. 391-398.

Mohammad A.,Sabaa A.K., 2015. In vitro and in vivo impact of some Pseudomonas spp. on growth and yield of cultivated mushroom (Agaricus bisporus). The Egyptian Society of Experimental Biology, 11(2): 163-167.

Özaktan H., Bora T., 1994. Kültür mantarında (Agaricus bisporus) Kahverengi benek etmeni (Pseudomonas tolaasii, Paine)'nin bazı fluoresent Pseudomonas izolatlarıla engellenmesi. Türkiye 3. Biyolojik Mücadele Kongresi, İzmir.
Özbayram K., Savaşkan Ç., 1983. Yemeklik mantar üretimi. T.C. Köy İşleri ve Kooperatifler Bakanlığı Topraksu Genel Müdürlüğü, Merkez, Topraksu Araştırma Enstitüsü Yayınları, Genel Yayın No:91, Çiftçi Yayın No: 8, s. 28.

Potocnik I., Stepanovic M., Rekanovic E., Todorovic B., Milijasevic-Marcic S., 2015. Disease control by chemical and biological fungicides in cultivated mushrooms: button mushroom, oyster mushroom and shiitake. Pesticides and Phytomedicine (Belgrade), 30(4): 201-208.

Romaine C.P., Ulhrich P., Schlagnhaufer B., 1993. Transmission of La France isometric virus during basidiosporogenesis in Agaricus bisporus. Mycologia, 85: 175-179.

Romaine C.P., Schlagnhaufer B., 1995. PCR analysis of the viral complex associated with la France disease of Agaricus bisporus. Applied and Environmental Microbiology, 61: 2322- 2325.

Sharma S.R., Kumar S., 2000. Studies on the wet bubble disease of white button mushrooms (Agaricus bisporus) caused by Mycogone perniciosa. Mushroom Science, 15: 569576.

Savoie J.M., Mata G., 2003. Trichoderma harzianum metabolites pre-adapt mushrooms to Trichoderma aggressivum antagonism. Mycology, 95 (2): 191-199.

Tajalipour S., Hassanzadeh N., Jolfaee H.K., Heydari A., Ghasemi A., 2014. Biological control of mushroom brown blotch disease using antagonistic bacteria. Biocontrol Science and Technology, 24: 473-484.

Umar M.H., Geels F.P.,Van Griensven L.J.L.D., 2000. Pathology and pathogenesis of Mycogone perniciosa infection in Agaricus bisporus. Mushroom Science, XV: 561-568.

Van Griensven L.J.L.D., 1988. Wet bubble (Mycogone perniciosa). The Cultivation of Mushrooms pp. 401-402.

Van Zaayen A.D., 1972. Mushroom virus disease in the Netherlands: Symptoms, etiology, electron microscopy, spread and control. Centre for Agricultural Publishing and Documentation, Wageningen, pp. 130.

Van Zaayen A., 1979. Mushroom viruses. in: viruses and plasmids in fungi (Ed.: P.A. Lemke). Marcel Dekker Inc. New York and Basel, pp. 240-324.

Wuest P.J., Bengston G.D., 1982. Penn state handbook for commercial mushroom 
growers. The Pennsylvania State

University, University Park, PA.

Wuest P.J., 1990. Sanitation and hygiene at the mushroom farm. Mushroom News April. 